\title{
Predation by birds on blue mussel Mytilus edulis beds of the tidal flats of Spiekeroog (southern North Sea)
}

\author{
G. Hilgerloh \\ Forschungszentrum Terramare, Schleusenstr. 1, D-26382 Wilhelmshaven, Germany
}

\begin{abstract}
Predation by birds on mussel beds was evaluated in the tidal flats of the East Frisian island Spiekeroog (Lower Saxony, Germany) based on measurements in 1991 and 1994. In May 1991, 32 locations with blue mussels Mytilus edulis covered an area of $5.2 \mathrm{~km}^{2}, 311 \mathrm{t}$ AFDW blue mussels being available in the whole study area. Areal extent decreased thereafter. In May 1994, there were 20 locations covering an area of only $2.3 \mathrm{~km}^{2}$, a total biomass of 48 t AFDW being available. After the strong spatfalls in the summers of both years, $1290 \mathrm{t}$ biomass were available in the study area in 1991, and 550 $t$ in 1994. Herring gulls Larus argentatus, oystercatchers Haematopus ostralegus and eiders Somateria mollissima are the main predators on blue mussels. During one year (1992), oystercatchers were present on 3.7 million bird days, elders on 1.1 million bird days and herring gulls on 0.7 million bird days. The annual consumption of blue mussels by birds in the intertidal flats was estimated at $165 \mathrm{t}$ AFDW. The highest proportion of total consumption was by oystercatchers $(54 \%)$, while eiders consumed $39 \%$ and herring gulls $7 \%$. Consumption by all 3 species amounted to $32 \mathrm{~g}$ AFDW per $\mathrm{m}^{2}$ of mussel bed in 1991 and to $71 \mathrm{~g}$ AFDW per $\mathrm{m}^{2}$ in 1994. Predation could be compensated by $12 \%$ of production in 1991 and by $29 \%$ in 1994. In order to evaluate the relevance of predation for the mussel stocks, the share of the total biomass eliminated annually by predation was assessed on the basis of standing stock and annual production. Predation was responsible for $7 \%$ of total elimination in 1991 and for $15 \%$ in 1994 . Thus, factors other than predation were responsible for 85 to $93 \%$ of elimination of mussel biomass
\end{abstract}

KEY WORDS: Predation - Tidal flats - Lower Saxony - Blue mussels Mytilus edulis - Oystercatchers Haematopus ostralegus . Eiders Somateria mollissima · Herring gulls Larus argentatus

\section{INTRODUCTION}

The stocks of blue mussels Mytilus edulis on the tidal flats of Lower Saxony (Germany) have decreased dramatically since the 1980s (Michaelis et al. 1995, Herlyn 1996), whereas the number of birds feeding mainly on mussels, such as herring gulls Larus argentatus, oystercatchers Haematopus ostralegus and eiders Somateria mollissima, have increased (Swennen et al. 1989, Exo 1994). It is not known whether the mussel beds have diminished because of bird predation or because of other factors such as pollution and commercial fishery. It is possible that the mussel stocks have been damaged so much by fishery and other factors that stress by predation can no longer be compensated. The question is how much consumption by birds can be sustained by a mussel population. The significant role of bird predation on mussel beds has been shown by several authors (Milne \& Dunnet 1971, Baird \& Milne 1981, Zwarts \& Drent 1981, Worral \& Widdows 1984, Craeymeersch et al. 1986, Egerrup \& Hoegh Laursen 1992, Faldborg et al. 1994, Nehls 1995). The influence of predation by birds was studied both on single mussel beds and in areas with many beds. Studies on single mussel beds are based on exclosure experiments, or on observations of the number of feeding birds, their feeding rate, the mean size of mussels eaten and their energy content, the duration of feeding time, and on biomass and production of the mussels. The evaluation of predation effects in an area including many mussel beds is 
generally based on several assumptions concerning mean daily consumption of a bird, number of birds, proportion of blue mussels in the food, extent of mussel stocks and average biomass per $\mathrm{m}^{2}$, and production of the mussels. Apart from the average daily consumption, which is determined by laboratory studies, most assumptions are based on local investigations.

In order to know whether predation effects can be compensated by production, the loss of biomass caused by predation is compared with the gain of biomass through production. If it is to be evaluated whether birds play a significant role in the development of the mussel beds, predation effects are assessed in relation to total elimination of biomass. Total elimination includes elimination by drift (current action), predation by birds, fishes, crabs and starfishes, and fisheries and other mortality factors

The present study is based on the biomass of the mussel stocks in 2 different years, and on the annual consumption by birds (eiders, oystercatchers and herring gulls) on the tidal flats of the island of Spiekeroog. Consumption was related to biomass, production and total elimination of blue mussels according to a simple model.

\section{MATERIAL AND METHODS}

The investigation was carried out on the tidal flats of Spiekeroog between the tidal watersheds of the islands of Wangerooge and Langeoog in the Wadden Sea of Lower Saxony (Fig. 1). The study area had an extent of $134 \mathrm{~km}^{2}$, composed of $110 \mathrm{~km}^{2}$ of intertidal and $24 \mathrm{~km}^{2}$ of sublittoral area.

The model. Evaluation of the influence of predation by herring gull, oystercatcher and eider on the stock of

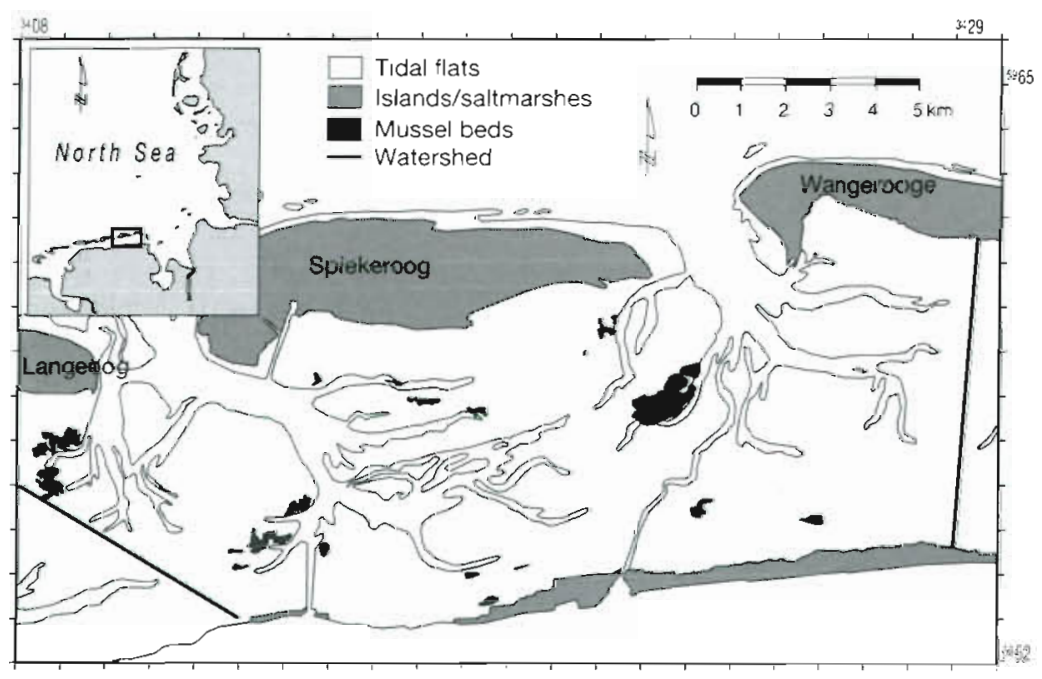

Fig. 1. Study area with mussel beds in 1994. (Data from Zens et al. 1996) blue mussels was carried out using a simple model, making assumptions mostly based on investigations in the study area. The following variables were involved.

(1) Areal extent of blue mussel beds. This was surveyed in May 1991 by Michaelis et al. (1995) and in May 1994 by Zens et al. (1996). Blue mussels growing sublittorally or on groynes were not included (for methods see below).

(2) Proportion of mussel beds with young mussels. Blue mussels spawn from March to October; the main spawning periods are in March, June and August/ September (Meyer-Waarden 1957). In 1994, 2 spatfalls took place, the first in April/May and the second and more intense one in June/July (M. Herlyn \& $\mathrm{H}$. Michaelis unpubl.). Areas containing young mussels were estimated in August 1994 by photos taken on black and white panchromatic films (G. Millat unpubl.). The total extent of blue mussel beds was the same as in May. In years with strong spatfalls (as in 1994) young mussels also settled in areas which did not contain mussels, so mature mussel beds must have decreased in summer. Since with this method areas which also included mature mussels could not be distinguished from areas which contained only young mussels, the summer decrease of mature mussel beds could not be determined. Methodological differences may have influenced the results. Of the total extent of mussel beds $70 \%$ was covered by young mussels from the same year. The same proportion was assumed for 1991 , as in both years recruitment was very strong. The model neglected that in in some areas with young mussels there must also have been mature mussels.

(3) Biomass per $\mathrm{m}^{2}$. For mature mussel beds the biomass was determined during the surveys of May 1991 and May 1994 (Michaelis et al. 1995, Zens et al. 1996) (for methods see below). For a mussel bed covered by young mussels, the biomass per $\mathrm{m}^{2}$ was determined in 1994 (Hilgerloh \& Herlyn 1996). Results were taken as representative for areas with young mussels in 1991 and 1994.

(4) Production per $\mathrm{m}^{2}$. The productivity of a mussel bed depends on the age of the mussels and reflects changes of abundance and of individual biomass. The productivity-biomass relationship $(P / B)$ of the mature mussel beds was estimated according to the frequency distribution of the mussel sizes and according to $P / B$ data evaluated for mussel beds of known frequency distributions of mussel size (Asmus 1987). For 1991, a P/B-ratio of 1.5 was assumed and for 1994 a ratio of 2. Production of young mussels was measured in 1994 on a young mussel 
bed (Hilgerloh \& Herlyn 1996) and taken as representative for production of young mussels. $P / B$ ratio was assumed to amount to 1 , based on the biomass in August.

(5) Bird days. Numbers of herring gulls and oystercatchers were counted on the ground (K. M. Exo unpubl.), and numbers of eiders from an aeroplane (for methods see below).

(6) Proportion of blue mussels in the food. The share of blue mussels in the food of eiders was assumed to amount to $80 \%$ in a year with high predation on blue mussels and to $68 \%$ in a year with low predation on blue mussels, following a 2 yr study performed on Langeoog and Spiekeroog in 1993 and 1994 (Hilgerloh in press a). The other most important prey item is the cockle Cerastoderma edule (Hilgerloh in press b). Based on the distribution of sublittoral mussel stocks and the concentration of eiders at groynes, it was assumed that $40 \%$ of the eiders fed on mussels growing on groynes, that $10 \%$ fed on mussels growing sublittorally, and that $50 \%$ fed on intertidally growing mussels. Herring gulls are omnivorous; they feed e.g. on fish, crabs, cockles and mussels in tidal flats but also on terrestrial prey items and garbage (Vauk \& Prüter 1987). For herring gulls, a share of 30 and $10 \%$ blue mussels in the food respectively for years with high and low predation on blue mussels was assumed in accordance with the literature (Meijering 1954, Focke 1959, Ehlert 1961, Spaans 1971, Wietfeld 1977, Prüter et al. 1988, Noordhuis \& Spaans 1992, Dernedde 1993) During some weeks, the share of blue mussels may be much higher, as was demonstrated by a study on Spiekeroog in the breeding period (Hilgerloh unpubl.). As in years with strong spatfall, the proportion of blue mussels in the food of eiders is higher than in years with less recruitment; for 1991 and 1994 a high proportion of blue mussels in the food of bird predators was assumed. On the tidal flats, oystercatchers mainly feed on molluscs, principally on mussels, cockles and Macoma balthica (Hulscher 1982). No studies are known about the proportion of the population which feeds on blue mussels. It was assumed that $50 \%$ of the population specialized on blue mussels.

(7) Daily food consumption. The daily consumption by oystercatchers, herring gulls and eiders was calculated according to literature sources (see below).

The budget presented here is a preliminary estimation; e.g. elimination by eiders is probably underestimated (Raffaelli et al. 1990) while that of herring gulls may be overestimated (they also feed on blue mussels growing on groynes).

Sampling of blue mussels. Samples of blue mussels were taken on 5 mature mussel beds. A mature mussel bed includes the seedling beds, which are characterized by distinct elevations formed by biodeposits like faeces and pseudofaeces of mussels as well as by mussel-free areas in between. Samples with a surface of $177 \mathrm{~cm}^{2}$ were taken in the most densely covered parts of the seedling beds ( 3 in 1991 and 12 in 1994), arbitrarily selected within the mussel bed. For calculation of biomass per $\mathrm{m}^{2}$ for the whole mussel bed, in 1991, coverage of the seedling beds by mussels as well as the coverage of the whole mussel bed by seedling beds was estimated. In 1994, the coverage of the seedling beds by mussels was measured along 5 transects running parallel over 12 seedling beds. Areas not covered by mussels were excluded if they were smaller than $177 \mathrm{~cm}^{2}$. The coverage of the mussel bed by seedling beds was measured along 3 to 5 parallel transects running over the whole mussel bed. The following variables were determined in May 1991 and 1994: coverage of the seedling beds by mussels, coverage of the mussel bed by seedling beds, frequency distribution of mussel sizes, abundance, fresh weight and ash free dry weight (AFDW) per $\mathrm{m}^{2}$.

On the young mussel bed 6 samples with a surface of $38.5 \mathrm{~cm}^{2}$ were taken at regular intervals along a transect running over the entire mussel bed (Hilgerloh \& Herlyn 1996).

Determination of biomass. The following formula was used to estimate the average biomass per $\mathrm{m}^{2}$ of the mussel bed $\left(B, \mathrm{~g} \mathrm{AFDW} \mathrm{m}^{-2}\right)$

$$
B=\left(B_{\mathrm{p}} \cdot S \cdot S^{\prime}\right) / 10000
$$

where $B_{\mathrm{p}}$ is the biomass per $\mathrm{m}^{2}$ in dense mussel parts of the seedling beds, $S$ is the coverage (\%) of the whole mussel bed by seedling beds, and $S^{\prime}$ is the coverage $(\%)$ of seedling beds by mussels.

In order to evaluate the exact extent of the mussel beds in the research area, observations were made by aeroplane and available aerial photographs were used. In some parts of the research area measurements on the bed (Hertweck 1992) were available for comparison.

Total biomass of the study area was calculated according to the following formula:

$$
B_{\mathrm{G}}=(B \cdot F)
$$

where $B_{\mathrm{G}}$ is the biomass of all mussel beds, and $F$ is the total areal extent of all mussel beds.

Determination of elimination of mussels. Elimination of biomass was determined according to the following function:

$$
E=\left(B_{1}+P_{1}\right)-B_{2}
$$

where $B_{1}$ is the biomass at date 1 and $P_{1}$ its annual production, and $B_{2}$ is the biomass at date 2 .

Determination of bird days. In the study area, subdivided into 6 counting areas, the numbers of roosting oystercatchers and herring gulls were estimated twice a month at spring tide between January and December 
1992 (Wangerooge: January to April, once a month; May and August, 3 times per month) (for methods see Rösne. 1992). Eider ducks had to be estimated from the air, as they often stay on the water during high tide. Herring gulls and oystercatchers were counted from the ground. Numbers of eiders were estimated from March to May 1993 once a month, and from June to October at least twice a month. Eider ducks were counted on $17 \mathrm{~d}$, mostly at low tide from an aeroplane flying along the channels, creeks and sandflats where they prefer to roost. In January 1993 and February 1994, numbers of eiders were estimated from other sources (National Park Administration unpubl., estimates by G. Nehls). Number of eiders during February, November, and December were interpolated linearly. Calculation of bird days (Laursen 1987) was based on the average number of birds per month. Ten birds seen on $1 \mathrm{~d}$ or 1 bird seen on $10 \mathrm{~d}$ correspond to 10 bird days.

Determination of daily food consumption. For a rough estimation of the daily food consumption, methods were used similar to those of Meire et al. (1994) for their estimation of consumption in the Oosterschelde (Netherlands). The resulting estimates may differ depending on the exact method used (Lasiewski \& Dawson 1967, Hulscher 1974, Hüppop 1987, Goede 1993). In this study, basal metabolic rate (BMR, in watts) is determined according to the formula

$$
\text { BMR }=5.06 \cdot \text { Weight }(\mathrm{kg})^{0.729}
$$

(Kersten \& Piersma 1987) for waders, and according to the formula

$$
\mathrm{BMR}=3.56 \cdot \text { Weight }(\mathrm{kg})^{0.734}
$$

(Aschoff \& Pohl 1970) for non-waders. The BMR value obtained was converted to $\mathrm{KJ} \mathrm{d}^{-1}$. Total daily energy expenditure (DEE) was assumed to amount to 3 times BMR (Smith 1975, Drent et al. 1978, Kersten \& Piersma 1987, Castro et al. 1992). For benthic invertebrates a digestibility of $Q=0.85$ was assumed (Kersten \& Piersma 1987, Zwarts \& Blomert 1992). Accordingly, the daily consumption was calculated by the formula.

$$
C=3 \cdot \operatorname{BMR} \cdot(1 / Q)
$$

Weights of herring gulls are known from the breeding period on the nearby island of Mellum (Goethe 1961); for oystercatchers monthly mean weights were available from The Netherlands (Swennen in Cramp \& Simmons 1977), so average daily consumption could be calculated for each month

For eiders, monthly consumption estimates are based on the relation between consumption and feeding time per day measured by Nehls (1995). In winter (January to March), eiders consumed $187 \mathrm{~g} \mathrm{AFDW} \mathrm{d}^{-1}$, and spent $22.6 \%$ of the day feeding. In summer (June/July), they consumed $130 \mathrm{~g} \mathrm{AFDW} \mathrm{d}^{-1}$, and spent $11.6 \%$ of the day feeding (Nehls 1995). The relationship between consumption and feeding time is best represented by a hyperbola. It has the following function

$$
y=(347.8270 x) /(x+19.4369)
$$

where $y$ is the consumption in $g$ AFDW, and $x$ is the daily feeding time expressed as percent of the day. This function was used to calculate the average daily consumption for each month.

The evaluation of AFDW was calculated in accordance with Jansson \& Wulff (1977) and H. Asmus (pers. comm.). Thus, $1 \mathrm{~g}$ AFDW of Mytilus edulis corresponds to $20.77 \mathrm{~kJ}$. Average daily consumption of blue mussels amounted to $51 \mathrm{~g}$ AFDW for a herring gull, 43 to $52 \mathrm{~g}$ AFDW for an oystercatcher, and 92 to $183 \mathrm{~g}$ AFDW for an eider in the different months.

\section{RESULTS}

\section{Biomass on blue mussel beds}

In May 1991, there were 32 locations with blue mussels in the study area. Together they covered an area of $5.2 \mathrm{~km}^{2}$, that is, $3.9 \%$ of the study area or $4.7 \%$ of its intertidal area. On average there were 225 individuals or $60 \mathrm{~g}$ AFDW on $1 \mathrm{~m}^{2}$ of mature mussel bed (Table 1). There was a total of $311 \mathrm{t}$ AFDW blue mussels in the study area at the time of the survey. The distribution of mussel sizes was bimodal: mussels were concentrated between 1 and $10 \mathrm{~mm}$ and between 45 and $70 \mathrm{~mm}$ (Fig. 2). The conspicuous gap from 10 to $45 \mathrm{~mm}$ was found on all mussel beds investigated.

In May 1994, 20 locations with blue mussels existed in the study area. Together they covered an area of $2.3 \mathrm{~km}^{2}$. This corresponded to $1.7 \%$ of the study area or $2.1 \%$ of the intertidal part. The coverage by mussel beds had diminished by $55 \%$ within 3 yr. The average abundance for mature beds a mounted to 586 blue mussels $\mathrm{m}^{-2}$ and the biomass to $21 \mathrm{~g} \mathrm{AFDW} \mathrm{m}^{-2}$ (Table 1 ). In 1994, there were 48 t AFDW blue mussels in the study area at the time of the survey. The distribution of mussel sizes had a maximum between 1 and $15 \mathrm{~mm}$ (Fig. 3). The second maximum found in 1991 (between 45 and $70 \mathrm{~mm}$ ) had nearly disappeared. Almost no mussels from the spatfalls of the years 1991 to 1993 were left.

On mussel beds covered by young mussels, 33390 mussels or $328 \mathrm{~g}$ AFDW m $\mathrm{m}^{-2}$ occurred (Hilgerloh \& HerIyn 1996). Totalling both young and mature mussel beds (1994 data assumed to apply also to 1991; see 'Material and methods'), there were 1290 t AFDW mussels in the study area in 1991 and 550 t in 1994 (Table 1). 
Table 1. Biomass, abundance, production and areal extent of mussel stocks in the backbarrier tidal flats of Spiekeroog; data on mature mussel beds from Michaelis et al. (1995) and Zens et al. (1996); data on young mussel bed from Herlyn \& Michaelis (unpubl.)

\begin{tabular}{|c|c|c|c|c|c|}
\hline & g AFDW m ${ }^{-2}$ & Abundance $\mathrm{m}^{-2}$ & $\begin{array}{l}\text { Areal extent } \\
\qquad\left(\mathrm{km}^{2}\right)\end{array}$ & $\begin{array}{l}\text { AFDW } \\
\text { (t) }\end{array}$ & $\begin{array}{c}\text { Production } \\
\text { (t) }\end{array}$ \\
\hline \multicolumn{6}{|l|}{1991} \\
\hline Mature mussel bed & $59.69 \pm 58.23$ & $225.46 \pm 214.38$ & 1.562 & 93.24 & 139.86 \\
\hline Young mussel bed & $328.44 \pm 101.69$ & $33390 \pm 10911$ & 3.644 & 1196.84 & 1196.84 \\
\hline Total & & & 5.206 & 1290.08 & 1336.70 \\
\hline Average $\mathrm{m}^{-2}$ & & & & 247.81 & 256.76 \\
\hline \multicolumn{6}{|l|}{1994} \\
\hline Mature mussel bed & $20.82 \pm 14.43$ & $585.80 \pm 630.86$ & 0.698 & 14.53 & 29.06 \\
\hline Young mussel bed & $328.44 \pm 101.69$ & $33390 \pm 10911$ & 1.629 & 535.03 & 535.84 \\
\hline Total & & & 2.327 & 549.56 & 564.90 \\
\hline Average $\mathrm{m}^{-2}$ & & & & 236.17 & 242.76 \\
\hline
\end{tabular}

\section{Bird days}

Average numbers of oystercatchers varied between 3200 and 15000 birds per month. Most of them were present from August to October 1992. Lowest numbers were observed from May to July (Fig. 4).

Average numbers of herring gulls varied among months between 700 and 4400 . Highest numbers occurred between May and December, lowest between January and April (Fig. 4). Average number of eiders varied between 1200 and 5800 . Highest numbers occurred in January. Between July and September, numbers reached a peak (Fig. 4). On an annual level, oystercatchers were present on the highest number of bird days ( 3.7 million). Eiders were present on 1.1 million bird days and herring gulls on 744000 bird days. Thus oystercatchers had a share of $66.42 \%$, herring gulls of $13.37 \%$ and eiders of $20.21 \%$ of total bird days for these species in the study area in one year.

\section{Consumption of blue mussels by birds}

Overall, 165 t AFDW blue mussels were consumed within 1 yr by oystercatchers, herring gulls and eiders (Table 2). Oystercatchers consumed the largest amount of blue mussels; they ate $54 \%$ while eiders accounted for $39 \%$ and herring gulls for $7 \%$ of total mussel consumption by these birds.

Highest predation pressure on mussel beds occurred in autumn and in winter (Fig. 5), mainly caused by
Fig. 2. Mytilus edulis. Size distribution of blue mussels in May 1991. (Data from Michaelis et al. 1995)

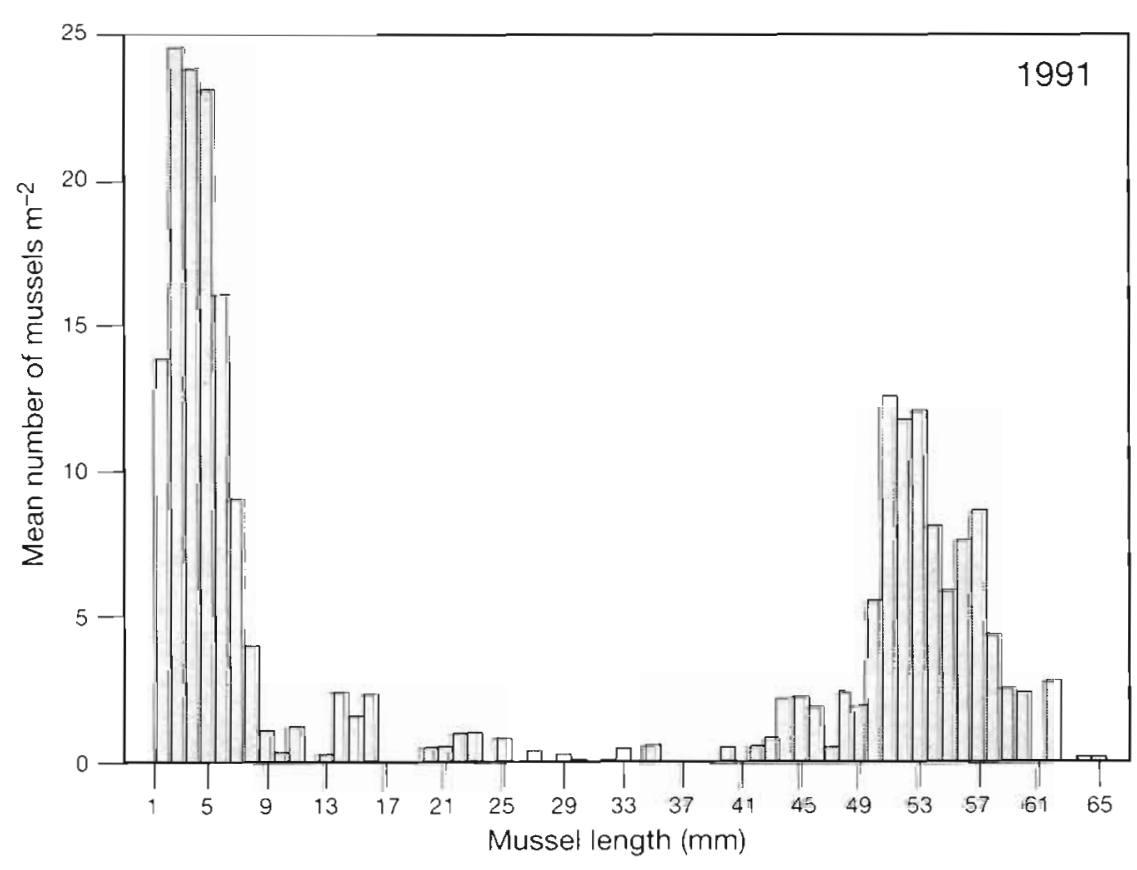




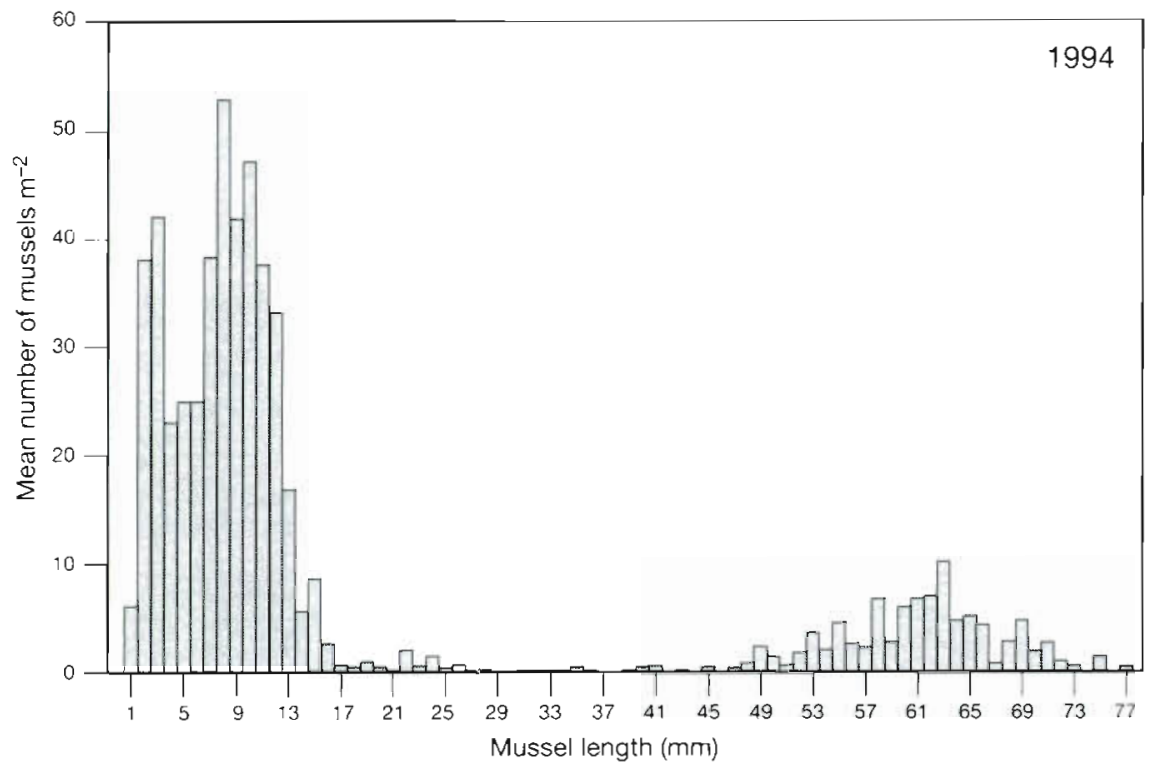

Fig. 3. Mytilus edulis. Size distribution of blue mussels in May 1994.

(Data from Zens et al. 1996) oystercatchers and eiders. For most of the year, oystercatchers had the highest share of total consumption, but in January and in June/July, it was eiders. During May/June, the absolute amount of consumption by all species was lowest.

Considering all food consumed by birds in 1992 in the study area, annual consumption by eiders amounted to $1.2 \mathrm{~g} \mathrm{AFDW} \mathrm{m}^{-2}$, by oystercatchers to $1.33 \mathrm{~g} \mathrm{AFDW}$ $\mathrm{m}^{-2}$ and by herring gulls to $0.28 \mathrm{~g} \mathrm{AFDW} \mathrm{m}^{-2}$. Oystercatchers and herring gulls feed only in the intertidal

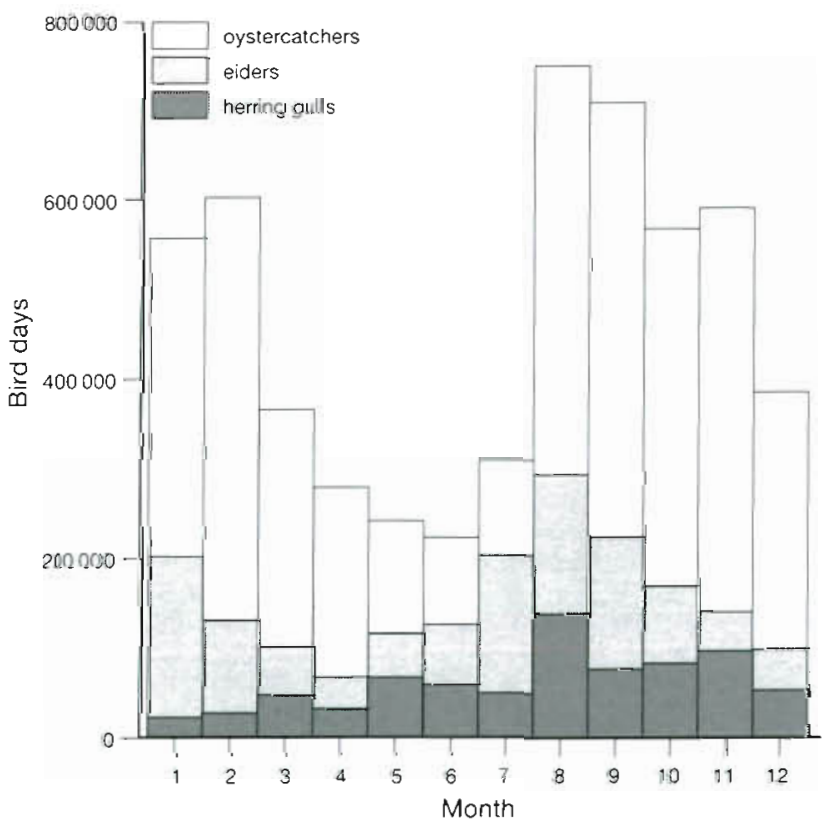

Fig. 4. Total number of bird days of oystercatchers, herring gulls. (Data trom Exo unpubl.) and eiders in the course of $1 \mathrm{yr}$ area where oystercatchers consumed $1.62 \mathrm{~g} \mathrm{AFDW} \mathrm{m}^{-2}$ and herring gulls $0.35 \mathrm{~g} \mathrm{AFDW} \mathrm{m}^{-2}$.

\section{Influence of predation on mussel biomass}

Because in 1994 the areal extent of mussel beds was $55 \%$ lower than in 1991, predation pressure by birds was higher in 1994. In 1991, $32 \mathrm{~g}$ AFDW were consumed on $1 \mathrm{~m}^{2}$ of mussel bed with $248 \mathrm{~g}$ available biomass. In 1994, the consumption on $1 \mathrm{~m}^{2}$ of mussel bed was twice as high as in 1991; it amounted to $71 \mathrm{~g}$ AFDW $\mathrm{m}^{-2}$, while $236 \mathrm{~g}$ biomass was available (Table 3). (Biomass per $\mathrm{m}^{2}$ mussel bed was extremely low in May 1991 and 1994. In both years it was compensated for by a strong spatfall later in the year.)

The question whether the loss of biomass due to predation by birds could be compensated for by production was studied in both years of the survey. While $12 \%$ of the production on the mussel beds was needed in 1991 to compensate for bird predation, $29 \%$ of the production was needed in 1994.

If we were to assume that predation by birds was the only elimination factor, the biomass per $\mathrm{m}^{2}$ would be extremely high at the end of the year (Table 5). In view of the actual development of the mussel populations on the tidal flats of Lower Saxony, it is more reasonable that at the end of a year, the biomass would be similar to that of May of that year. The elimination would amount to $88 \%$ of the available biomass in 1991 and to $96 \%$ in 1994 . In order to evaluate the relevance of predation for the development of the mussels, the share that predation represents in proportion to total elimination must be calculated. This proportion amounted to $7 \%$ in 1991 and to $15 \%$ in 1994 (Table 6). 
Table 2. Per-day demands of mussel biomass and its monthly variation annual bird days and total consumption according to the model. Data on bird days of oystercatchers and herring gulls from Exo (unpubl.)

\begin{tabular}{|lcrc|}
\hline Species & $\begin{array}{c}\text { Mussel demand } \\
\mathrm{d}^{-1} \text { bird }^{-1} \text { (g AFDW) }\end{array}$ & $\begin{array}{c}\text { Bird days } \\
\mathrm{yr}^{-1}\end{array}$ & $\begin{array}{c}\text { Consumption yr } \\
\text { (t AFDW) }\end{array}$ \\
\hline Oystercatchers & $43-51$ & 1848139 & 89 \\
Herring gulls & 15 & 744148 & 11 \\
Eiders & $74-151$ & 56266 & 65 \\
\hline
\end{tabular}

\section{DISCUSSION}

\section{Development of the mussel stocks}

The surveys of the mussel beds in the study area demonstrate a decrease in the area covered by mussel beds by $55 \%$ between 1991 and 1994 . There has been a strong decrease of areal extent throughout the tidal flats of Lower Saxony since the mid 1980s (Michaelis et al. 1995, Zens et al. 1996).

During the 2 years studied, biomass per $\mathrm{m}^{2}$ was characterized by strong fluctuations which will have an effect on the availability of mussels for predators. At the beginning of a year, biomass was very low; later on, intensive spatfalls occurred and biomass increased by a factor of at least 4 . Biomass per $\mathrm{m}^{2}$ of the mussel beds was similar to that found in a Dutch study

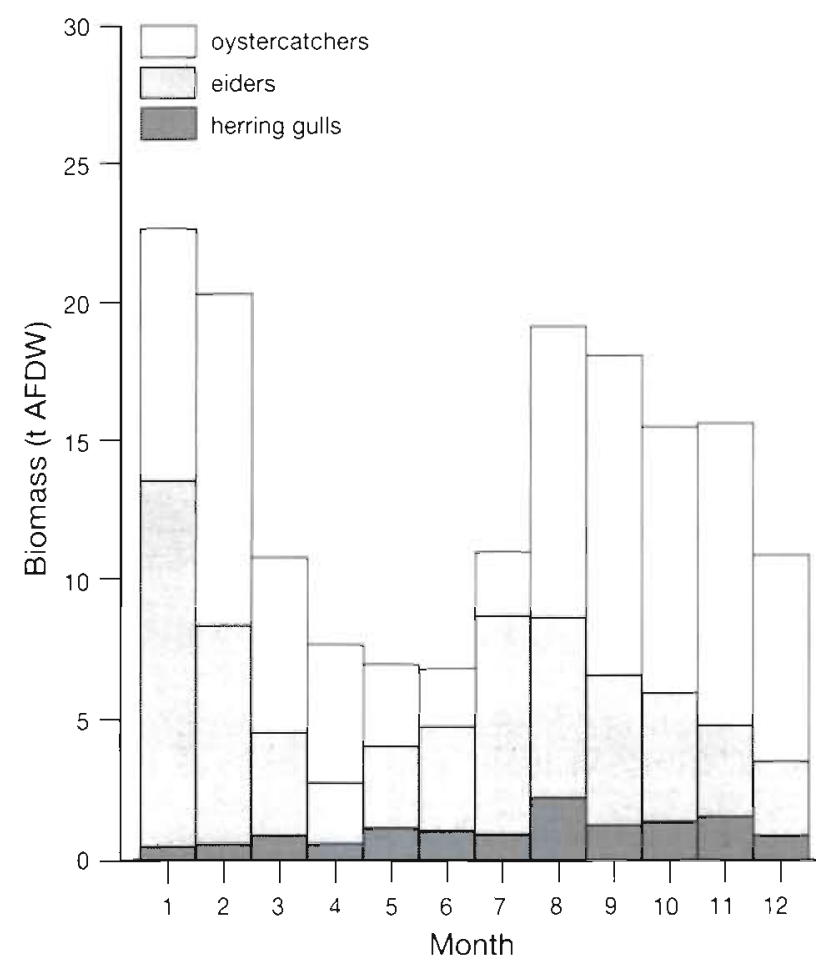

Fig 5. Mytilus edulis. Consumption of blue mussels by birds
(Craeymeersch et al. 1986). However, it amounted to only 15 to $20 \%$ of the biomass on mussel beds in some other areas (Dare 1976. Asmus 1987, Faldborg et al. 1994).

In 1991, $1290 \mathrm{t}$ biomass of blue mussels was available in the study area, which measured $134 \mathrm{~km}^{2}$; a similar amount of biomass was found in the mussel stocks growing on hard bottoms at the Swedish coast, $1500 \mathrm{t}$ being available in an area of $160 \mathrm{~km}^{2}$ (Kautsky 1981).

On the basis of the frequency distribution of mussel size, it seems that not each spatfall can have been established successfully in a mussel bed. Failure may occur more often in the tidal flats of the East Frisian islands than in other areas of the southern North Sea such as the Königshafen on the island of Sylt or the Jadebusen which are more protected from westerly winds (see Asmus 1987, Obert \& Michaelis 1991, Michaelis et al. 1995, Zens et al. 1996). The effects of different eliminating factors may result in a population structure missing size classes in an otherwise continuous size spectrum representing several years (Obert \& Michaelis 1991. Michaelis pers. comm.). Apparently the current situation is that even years with extremely strong spatfalls such as 1991 cannot contribute to a long-living cohort of mussels. Sites exist where young mussels failed to settle over a period of 10 yr (Zwarts \& Drent 1981). As mussels escape predation by growing out of the size range exploited by predators, it is quite possible that recruitment can be guaranteed by large mussels which will not be eaten (Paine 1974, 1976, 1985). The phenomenon of the dominance of one age class in a population is found in various forms of life such as fishes, frogs and trees (Ebenmann \& Persson 1988, Remmert 1991, Mertens \& Remmert 1992). Although the reasons for this may differ between species, the result is however the same (Mertens \& Remmert 1992).

In accordance with the low number of mature mussels on the tidal flats of Lower Saxony and the strong spatfalls in both years of study, the mussel populations

Table 3 . Consumption of blue mussels by oystercatchers, herring gulls and eiders in relation to $\mathrm{m}^{2}$ of the mussel beds

\begin{tabular}{|c|c|c|c|c|}
\hline & $\begin{array}{l}\text { Oyster- } \\
\text { catcher }\end{array}$ & $\begin{array}{l}\text { Herring } \\
\text { gull }\end{array}$ & Eider & Total \\
\hline $\begin{array}{l}1991 \\
\text { g AFDW m-2 } \mathrm{yr}^{-1} \\
\text { mussel bed }\end{array}$ & 17.10 & 2.11 & 12.49 & 31.70 \\
\hline $\begin{array}{l}1994 \\
\text { g AFDW m-2 } \mathrm{yr}^{-1} \\
\text { mussel bed }\end{array}$ & 38.25 & 4.73 & 27.93 & 70.91 \\
\hline
\end{tabular}


Table 4. Comparison of the gain of biomass by production with the loss of biomass by predation

\begin{tabular}{|lrr|}
\hline & 1991 & 1994 \\
\hline Biomass (g AFDW) m ${ }^{-2}$ & 247.81 & 236.17 \\
Production (g AFDW) m-2 $\mathrm{yr}^{-1}$ & 256.76 & 242.76 \\
Predation (g AFDW) m $\mathrm{yr}^{-1}$ & 31.69 & 70.91 \\
Predation as \% of production & 12.34 & 29.21 \\
\hline
\end{tabular}

Table 5. Development of mussel beds, if predation were the only elimination factor

\begin{tabular}{|lll|}
\hline & 1991 & 1994 \\
\hline Biomass at the beginning (t AFDW) & 1290.08 & 549.56 \\
Production yr ${ }^{-1}$ (t AFDW) & 1336.70 & 564.90 \\
Predation yr ${ }^{-1}$ (t AFDW) & 165 & 165 \\
Biomass at the end (t AFDW) & 2461.78 & 949.46 \\
\hline
\end{tabular}

Table 6. Share of predation out of total elimination

\begin{tabular}{|lcc|}
\hline & 1991 & 1994 \\
\hline Biomass (t AFDW) & 1290.08 & 549.56 \\
Production (g AFDW) & 1336.70 & 564.90 \\
Elimination (g AFDW) & 2315.78 & 1066.46 \\
Elimination as \% of & 88 & 96 \\
$\quad$ biomass and production & 7 & 15 \\
Predation as \% of elimination & 311 & 48 \\
Biomass at the end (t AFDW) & & \\
\hline
\end{tabular}

were dominated by first year mussels during summer and autumn. Production was high, as can be expected in young mussel populations, but lower than on the mussel bed of Morecambe Bay, NW England (Dare 1976), where mortality during the first year was exceptionally low. However, in this study, elimination in the course of the first year seems to have been extremely high, so that after the first winter the mussel population reverted to its initial size.

\section{Influence of predation on mussel biomass}

Predation pressure by birds on $1 \mathrm{~m}^{2}$ of mussel bed differed in the 2 years studied according to differences in the areal extent of mussel beds. At $32 \mathrm{~g}$ and $71 \mathrm{~g} \mathrm{~m}^{-2}$ for 1991 and 1994 respectively, predation pressure by oystercatchers, herring gulls and eiders was low compared to that on mussel beds in the Danish and Dutch Wadden Sea (Craeymeersch et al. 1986, Egerrup \& Hoegh Laursen 1992, Faldborg et al. 1994). In a Danish study on the mussel beds of the Hobo Dyb near the island Langli, a similar approach as in the present study was used (Faldborg et al. 1994). The potential predation pressure was estimated at $300 \mathrm{~g} \mathrm{~m}^{-2}$ assuming that $100 \%$ of the food of all 3 species consisted of blue mussels living on the intertidal flats. Exclosure experiments on a single mussel bed of the Danish Wadden Sea revealed a consumption of $116 \mathrm{~g}$ AFDW $\mathrm{m}^{-2}$ by mainly oystercatchers and eiders (Egerrup \& Hoegh Laursen 1992) and, in the Dutch Wadden Sea, a consumption of $48 \mathrm{~g} \mathrm{AFDW} \mathrm{m}^{-2}$ by oystercatchers was evaluated by observations (Craeymeersch et al. 1986). Although the consumption varies between months, there is much more evenness of demand than in mortality by physical factors. This is important as the impact on the mussels will be different if very large numbers of birds were present for a short period instead of moderate numbers for a long period.

According to an estimation of predation pressure by eiders in the whole Wadden Sea area (Swennen et al.

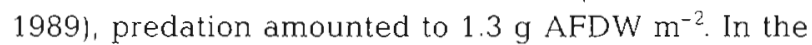
present study area, predation pressure was the same as the overall average for the whole Wadden Sea.

Consumption by birds could be compensated by 12 and $29 \%$ of production in the study area. As in my study area only a few mature mussels were available and 2 years with a strong spatfall were investigated, the production was high and predation accounted for a small proportion of production. Predation in relation to production was low compared to other studies (Table 7), although numbers of birds predating on mussels had increased in the tidal flats of Lower Saxony (Exo 1994, Meltofte et al. 1994). Apparently, stable mussel populations sustain a high yield to birds which can amount to about $70 \%$ of total mussel production of an area or even to $95 \%$ on a single mussel bed without destabilizing the mussel population. It is not known whether the maximal sustainable yield was removed in the different study areas. Only if ice and storms destroy mussel beds, as occurs in the tidal flats of Lower Saxony (Flemming \& Delafontaine 1994, Hilgerloh \& Herlyn 1996), can we be sure that physical factors are controlling the mussel population.

In an area with a strong decrease of blue mussel beds like Lower Saxony the total loss of biomass exceeds the production. In order to recognize the significance of predation by birds for the development of the mussel beds, it has to be known what proportion of total elimination they consumed. In the study area, predation by birds accounted for $7 \%$ and for $15 \%$ of total elimination in 1991 and 1994 respectively. These are low values compared to the results in Denmark (Egerrup \& Hoegh Laursen 1992, Faldborg et al. 1994) but similar to those for the Lynher estuary, SW England (Worral \& Widdows 1984). In Denmark, according to Egerrup \& Hoegh Laursen (1992) predation accounted for $52 \%$ of elimination and according to Faldborg et al. (1994) for $64 \%$. From exclosure experiments in the 
Table 7. Annual consumption by birds compared to total production and standing stock on eulittoral natural mussel beds. Standing stock is defined as the mean annual biomass (in parentheses: biomass in summer)

\begin{tabular}{|c|c|c|c|c|c|}
\hline Area & $\begin{array}{l}\text { Consumption } \\
\text { compared to the } \\
\text { production ( }\end{array}$ & $\begin{array}{c}\text { Consumption } \\
\text { compared to the } \\
\text { standing stock }(\%)\end{array}$ & $\begin{array}{l}\text { Predating } \\
\text { species }\end{array}$ & $\begin{array}{l}\text { Mussel } \\
\text { stock }\end{array}$ & Source \\
\hline \multicolumn{6}{|c|}{ Areas including several mussel beds } \\
\hline $\begin{array}{l}\text { Tidal flats of } \\
\text { Spiekeroog }\end{array}$ & 12 & (13) & $\begin{array}{l}\text { Oystercatchers, eiders } \\
\text { and herring gulls }\end{array}$ & Decreasing & This study \\
\hline Tidal flats of Spiekeroog & 29 & $(30)$ & & Decreasing & This study \\
\hline Ythan estuary, Scotland & 71 & 72 & & Stable & Baırd \& Milne (1981) \\
\hline Ythan estuary, Scotland & 67 & 37 & & Stable & Milne \& Dunnet (1972) \\
\hline Hobo Dyb. Denmark & 45 & 32 & & Stable & Faldborg et al (1994) \\
\hline Askö area, Sweden & $?$ & 0.15 & Eiders & Stable & Kautsky (1981) \\
\hline \multicolumn{6}{|l|}{ Single mussel beds } \\
\hline Hobo Dyb, Denmark & 81 & 17 & $\begin{array}{l}\text { Oystercatchers } \\
\text { and eiders }\end{array}$ & Stable & $\begin{array}{l}\text { Egerrup \& } \\
\text { Hoegh Laursen (1992) }\end{array}$ \\
\hline Königshafen, Germany & 95 & 33 & & Stable & Nehls (1995) \\
\hline $\begin{array}{l}\text { Eastern Scheldt estuary, } \\
\text { Netherlands }\end{array}$ & 40 & 20 & Oystercatchers & Stable & $\begin{array}{l}\text { Craeymeersch et al. } \\
(1986)\end{array}$ \\
\hline
\end{tabular}

Lynher estuary, Worral \& Widdows (1984) concluded that birds accounted for $16 \%$ of total elimination. The small proportion of total elimination accounted for by consumption in the study area can be explained by the high total elimination. A similar relationship was found on a newly settled mussel bed of the tidal flats of Spiekeroog, which disappeared during the first winter (Hilgerloh \& Herlyn 1996). Thus, in an area of decreasing mussel stocks, predation is an elimination factor of minor importance, while on stable mussel beds predation accounts for a high proportion of biomass loss.

Other factors were responsible for 85 and $93 \%$ of the loss of biomass within a year and for the decrease in areal extent between the years. In particular, young mussels suffer high mortality due to other factors (McGrorty et al. 1990, Gosling 1992), and the proportion of young mussels was very high in the studied years. The main invertebrate predator on small mussels is the shore crab Carcinus maenas (Davies et al. 1980). Their predation is limited to spring and summer, as in winter they leave the intertidal area (Reise 1985). While size selection by crabs of different sizes has been studied (Jubb et al. 1983), no quantitative data are available about the impact of crab predation on mussel beds. It is even not proven if the demand of young crabs for progressively bigger sizes of mussels can be satisfied by the growing first-year mussels.

Fishes, especially flounders Platichthys flesus L. and plaice Pleuronectes platessa, also predate on young mussels (Dare 1976). The seasonal fluctuations and the impact on mussels have not as yet been studied.

Man as a predator has become an important elimination factor, as the amount of mussels taken by fishery has increased continuously during the last 40 yr, which has surely damaged the mussel population (Herlyn 1996). In Lower Saxony seed mussels are taken from natural mussel beds and brought to culture plots where they grow to commercial size. Whether the impact of fishery influences their vulnerability to other mortality factors is as yet not known. However, the decrease in those mussel beds used by fishery does not exceed that in mussel beds left untouched (Herlyn 1996).

It is not known whether there is an increase of parasitic infection in blue mussels, which would lead to a higher mortality (Lauckner 1994).

Substantial overgrowth by macroalgae has a negative effect on mussels, as the flow in the boundary layer decreases and sedimentation increases. As a result of eutrophication, algal growth has increased since the beginning of the 1980s (Reise et al. 1993) This factor will probably not be of importance for the decrease of mussel stocks in Lower Saxony (Herlyn 1996).

Algal blooms of Phaeocystis globosa are suspected to have a negative effect on mussels (e.g. Pieters et al. 1980). Although the clearance rate decreased during such blooms according to mesocosm experiments (Prins et al. 1995), feeding with P. globosa in laboratory experiments led to an increase of mussel biomass (Petri \& Vareschi in press).

Blue mussels are relatively highly contaminated by polychlorinated biphenyls and heavy metals (Bakker 1994. Pfaffenberger et al. 1994). It is striking that the strongest decrease in the mussel population took place in the extremely contaminated Weser river estuary. Contaminated mussels could be more vulnerable to physical factors.

The strong eliminating effect of physical factors leaves the most easily recognizable traces on the mussel beds. Large patches without any mussels can be seen after storms and young mussel beds often disappear completely after the tidal flats have been covered 
by ice. Physical factors show strong seasonal variations. The damaging effects of high temperatures, ice crushing or scouring, storm-generated waves and wave-driven logs, and excessive levels of silt and inorganic detritus, as well as biodeposits, are well documented (Gosling 1992, Nehls \& Thiel 1993, Flemming \& Delafontaine 1994). However, as some factors are density dependent (Gosling 1992), the timing and extent of elimination by other factors may affect the vulnerability of mussels to physical factors. The damaging effect will be much higher if the mussels have become more vulnerable by the effects of other factors (e.g. contamination). As storm surges in the tidal flats of Lower Saxony were twice as frequent in the period from 1970 to 1994 than in the period from 1946 to 1969 (Niemeyer et al. 1995), this, together with mussel weakening effects by other factors, may be one of the major reasons for the decrease of the mussel beds.

Acknowledgements. I would like to express my sincere thanks to my colleagues $M$. Exo, H. Michaelis, H. Asmus, M. Herlyn, G. Scheiffarth, C. Ketzenberg and G. Nehls for many discussions and especially to $\mathrm{M}$. Exo and $\mathrm{H}$. Asmus for critically reading the manuscript. $H$. Michaelis and $M$. Zens are thanked for the data of the blue mussel surveys from 1991 and 1994 for this study. M. Exo was kind enough to provide the data on counts of oystercatchers and herring gulls, which were performed by collaborators of the Wissenschaftliche Arbeitsgemeinschaft für Natur und Umweltschutz e.V. (WAU), Jever, of the Staatliches Amt für Insel- und Küstenschutz (STAIK), Norden, of the Institut fur Vogelforschung 'Vogelwarte Helgoland', Wilhelmshaven, and of the Mellumrat e.V. Oldenburg. I am grateful to D. Pfeifer for his help in calculating the function for the relation between the consumption and feeding time of eiders, R. Hasbargen for his support in counting the eiders from an aeroplane, $M$. Reetz for the digital processing of Fig. 1 and R. Pocklington and $M$. Delafontaine for help with language corrections. The study was supported by the Federal Environmental Agency, Environmental Research Plan of the Minister for the Environment, Nature Conservation and Nuclear Safety of the Federal Republic of Germany (Grant 10802 085/21), and by the state of Lower Saxony. This is publication no. 241 of the project Ecosystem Research Wadden Sea.

\section{LITERATURE CITED}

Aschoff J, Pohl H (1970) Der Ruheumsatz von Vögeln als Funktion der Tageszeit und der Körpergröße. J Ornithol $111: 38-47$

Asmus $H$ (1987) Secondary production of an intertidal mussel bed community related to its storage and turnover compartments. Mar Ecol Prog Ser 39:251-266

Bakker JF (1994) Schadstoffe in Miesmuscheln. In: Lozán $J L$, Rachor $E$, Reise $K, v$ Westernhagen $H$, Lenz $W$ (eds) Warnsignale aus dem Wattenmeer. Blackwell Wissenschafts-Verlag, Berlin, p 132-143

Baird D, Milne H (1981) Energy flow in the Ythan estuary, Aberdeenshire, Scotland. Estuar Coast Shelf Sci 13: $455-472$
Castro G, Myers JP, Ricklefs RE (1992) Ecology and energetics of Sanderlings migrating to four different latitudes. Ecology 73:833-844

Craeymeersch JA., Herman PMJ, Meire PM (1986) Secondary production of an intertidal mussel (Mythlus edulis L.) population in the Eastern Scheldt (SW-Netherlands). Hydrobiologia 133:107-115

Cramp S, Simmons KEL (1977) Handbook of the birds of Europe and the Middle East, Vol 1. Oxford University Press, Oxford

Dare PJ (1976) Settlement, growth and production of the mussel, Mytilus edulis L. in Morecambe Bay, England Fish Invest Ser II Mar Fish GBMinist Agric Fish Food 28(1): $1-25$

Davies G, Dare PJ, Edwards DB (1980) Fenced enclosures for the protection of seed mussels (Mytilus edulis L.) from predation by shore-crabs [Carcinus maenas (L.)]. Fish Invest Ser II Mar Fish G B Minist Agric Fish Food 56:1-14

Dernedde T (1993) Vergleichende Untersuchungen zur Nahrungszusammensetzung von Silbermöwe (Larus argentatus). Sturmmöwe (L. canus) und Lachmöwe (L. ridibundus) im Königshafen/Sylt. Corax 15:222-240

Drent R, Ebbinge B, Weljand $\mathrm{B}$ (1.978) Balancing the energy budgets of arctic-breeding geese throughout the annual cycle: a progress report. Verh On Ges Bayern 23:239-263

Ebenmann B, Persson L (ads) (1988) Size-structured populations. Springer, Berlin

Egerrup M. Hoegh Laursen ML (1992) Aspects of predation on intertidal blue mussels (Mytilus edulis L.) in the Danish Wadden Sea. International Council for Exploration of the Sea, Shellfish Committee: $1-20$

Ehlert W (1961) Weitere Untersuchungen über die Nahrungswelt der Silbermöwe (Larus argentatus) auf Mellum. Vogelwarte 21:48-50

Exo KM (1994) Bedeutung des Wattenmeeres für Vögel. In:

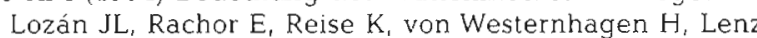
$W$ (eds) Warnsignale des Wattenmeeres. Blackwell Wissenschafts-Verlag, Berlin, p 261-270

Faldborg K, Jensen KT, Maargaard L (1994) Dynamics, growth, secondary production and elimination by waterfowl of an intertidal population of Mytilus edulis L. Ophelia Suppl $6: 187-200$

Flemming BW, Delafontaine MT (1994) Biodeposition in a juvenile mussel bed of the East Frisian Wadden Sea (southern North Sea). Neth J Aquat Ecol 28(3-4):289-297

Focke E (1959) Zur Ernährung der Silbermöwe (Larus argentatus). Vogelwarte 20:86-88

Goede AA (1993) Variation in the energy intake of captive Oystercatchers Haematopus ostralegus. Ardea 81:89-97

Goethe F (1961) Zur Taxonomie der Silbermöwe im südlıchen deutschen Nordseegebiet. Vogelwarte 21:1-24

Gosling E (ed) (1992) The mussel Mytilus: ecology, physiology, genetics and culture. Developments in Aquaculture and Fisheries Science 25. Elsevier, Amsterdam

Herlyn M (1996) Zur Bestandssituation der Miesmuschelbänke des niedersächsischen Wattenmeeres. Mitteilungen der Norddeutschen Naturschutzakademie, Schneverdingen 1:5-61

Hertweck G (1992) Distribution of benthos and Lebensspuren in the Spiekeroog backbarrier tidal flai area (southern North Sea). Cour Forsch-Inst Senckenberg 127:343-353

Hilgerloh G (in press a) Miesmuscheln (Mytilus edulss) in der Nahrung der Eiderenten (Somateria mollissima) auf Spiekeroog und Langeoog. Acta Ornithoecologica, Jena

Hilgerloh G (in press b) Die Nahrung der Eiderenten im Nationalpark Niedersächsisches Wattenmeer. In: Umweltbundesamt \& Nationalparkverwaltung Niedersachsisches 
Wattenmeer. Umweltatlas Vol. Il (Ostfriesisches Wattenmeer und Hohe Weg Watt, Neuwerker und Wurster Wattenmeer). Ulmer Verlag, Stuttgart

Hilgerloh G, Herlyn M (1996) Auswirkungen der Prädation durch Vogel auf eine junge Miesmuschelbank (Mytilus edulis). Verh Dtsch Zool Ges 89:306

Hüppop O (1987) Der Einfluß von Wachstum, Thermoregulation und Verhalten auf den Energiehaushalt der Silbermöwe (Larus argentatus Pontoppidan, 1763). Diss Universität Hamburg

Hulscher JB (1974) An experimental study of the food intake of the Oystercatcher Haematopus ostralegus L. in captivity during the summer. Ardea 62:155-171

Hulscher J (1982) The Oystercatcher Haematopus ostralegus as a predator of the bivalve Macoma balthica in the Dutch Wadden Sea. Ardea 70:89-152

Jansson BO, Wulff $F$ (1977) Ecosystem analysis of shallow sound in the northern Baltic - a joint study by the Asko group. Contr Askö Lab, Department of Zoology, University of Stockholm 18:1-160

Jubb CA, Hughes RN, Rheinalt AP (1983) Behavioural mechanisms of size-selection by crabs, Carcinus maenas, feeding on mussels, Mytilus edulis. J Exp Mar Biol Ecol 66:81-87

Kautsky $N$ (1981) On the trophic role of the blue mussel (Mytilus edulis L.) in a Baltic coastal ecosystem and the fate of the organic matter produced by the mussels. Kieler Meeresforsch Sonderh 5:454-461

Kersten M, Piersma T (1987) High levels of energy expenditure in shorebirds; metabolic adaptations to an energetically expensive way of life. Ardea 75:175-187

Lasiewski RC, Dawson WR (1967) A re-examination of the relation between standard metabolic rate and body weight in birds. Condor 69:13-23

Lauckner G (1994) Parasiten als bestandregulierender Faktor im Watt. In: Lozán JL, Rachor E, Reise K, von Westernhagen $\mathrm{H}$, Lenz $\mathrm{W}$ (eds) Warnsignale des Wattenmeeres. Blackwell, Berlin, p 144-149

Laursen K (1987) Consumption of mussels by Eiders in the Danish Wadden Sea. In: Tougaard S, Aasbirk S (eds) Proc 5th int Wadden Sea Symp. The National Forest and Nature Agency and the Museum of Fishery and Shipping, Esbjerg, p 239-245

McGrorty S, Clarke RT, Reading CJ, Goss-Custard JD (1990) Population dynamics of the mussel Mytilus edulis: density changes and regulation of the population in the Exe estuary, Devon. Mar Ecol Prog Ser 67:157-169

Meijering MPD (1954) Zur Frage der Variation in der Ernährung der Silbermöwe, Larus argentatus Pont. Ardea 42:163-175

Meire PM, Schekkerman H, Meininger PL (1994) Consumption of benthic invertebrates by waterbirds in the Oosterschelde estuary, SW Netherlands. Hydrobiol 282/283: $525-546$

Meltofte H, Blew J, Frikke J, Rösner HU, Smit CJ (1994) Numbers and distribution of waterbirds in the Wadden Sea. Results and evaluation of 36 simultaneous counts in the Dutch-German-Dansk Wadden Sea 1980-1991. IWRB Publ 34, Wader Study Group Bull 74, Special issue: 1-193

Mertens D, Remmert H (1992) Altersklassen-Populationen bei Grünfröschen. Naturwiss 79:377-378

Meyer-Waarden PF (1957) 2. Teil: Muscheltiere. In: MeyerWaarden PF, Tiews $\mathrm{K}$ (eds) Krebs- und Muscheltiere. Arbeiten des Deutschen Fischerei-Verbandes 9, Union der Berufs- und Sportfischer, Hamburg, p 1-68

Michaelis H, Obert B, Schultenkötter I (1995) Die Miesmuschelbestände der niedersächsischen Watten 1989-1991. Berichte der Forschungsstelle Küste, Nir. 40, Norderney
Milne H, Dunnet GM (1972) Standing crop, productivity and trophic relations of the fauna of the Ythan Estuary. In Barnes RSK, Green J (eds) The estuarine environment Applied Science Publishers, London, p 86-106

Nehls G (1995) Strategien der Ernährung und ihre Bedeutung für Energiehaushalt und Ökologie der Eiderente (Somateria mollissima (L., 1758). Dissertation, University of Kie

Nehls G. Thiel M (1993) Large-scale distribution patterns of the mussel Mytilus edulis in the Wadden Sea of Schleswig-Holstein: do storms structure the ecosystem? Neth J Sea Res 31:181-187

Niemeyer HD, Kaiser R, Glaser, D (1995) Sturmfluthäufigkeiten zwischen Ems und Weser von 1946-1994. Pegel Emden, Borkum, Norderney, Bremerhaven. Berichte der Forschungsstelle Küste, Norderney

Noordhuis R, Spaans AL (1992) Interspecific competition for food between Herring Larus argentatus and Lesser Blackbacked Gulls $L$. fuscus in the Dutch Wadden Sea area Ardea 80:115-132

Obert B, Michaelis H (1991) History and ecology of the mussel beds (Mytilus edulis L.) in the catchment area of a Wadden Sea tidal inlet. In: Elliot M, Ducrotoy PJ (eds) Estuaries and coasts: spatial and temporal intercomparisons. Olsen \& Olsen, Fredensborg, p 185-194

Paine RT (1974) Intertidal community structure: experimental studies on the relationship between a dominant competitor and its principal predator. Oecologia 15:93-120

Paine RT (1976) Size-limited predation: an observational and experimental approach with the Mytilus-Pisaster interaction. Ecology 57:858-873

Paine RT (1985) Perturbation and recovery patterns of starfish-dominated intertidal assemblages in Chile, New Zealand, and Washington State. Am Nat 125:679-691

Petri G. Vareschi E (in press) Utilization of Phaeocystis globosa colonies by young Mytilus edulis. Archive of Fishery and Marine Research

Pfaffenberger B, Huhnerfuß $H$, Landgraff O, Karbe L (1994) Seasonal variation of the toxic potential of coplanar polychlorinated biphenyls in blue mussel (Mytilus edulis L.) from the German Bight. Berichte Zentr Meeres- $u$ Klimaforsch, Hamburg, Reihe E, 7:121-137

Pieters H, Kluytmans JH, Zaudee DJ, Cadée GC (1980) Tissue composition and reproduction of Mytilus edulis in relation to food availability. Neth J Sea Res 14:349-361

Prins TC, Excaravage V, Smaal AC, Peeters JCH (1995) Nutrient cycling and phytoplankton dynamics in relation to mussel grazing in a mesocosm experiment. Ophelia 41:289-315

Prüter J, Sahmow A, Vauk-Hentzelt E (1988) Untersuchungen zur Ernährung der Silbermöwe (Larus argentatus) auf der Insel Scharhörn (Elbmündung) während der Brutzeit. Seevögel (Zeitschr des Vereins Jordsand, D-22926 Ahrensburg) $9: 56-58$

Raffaelli D, Falcy C, Galbraith C (1990) Eider predation and the dynamics of mussel bed communities. In: Varnes $M$, Gibson RN (eds) Trophic relations in the marine environment. Aberdeen Univ. Press, p 157-169

Reise K (1985) Tidal flat ecology: an experimental approach to species interactions. Ecol Stud 54. Springer, Berlin

Reise K. Asmus R, Asmus H. (1993) Okosystem Wattenmeer Das Wechselspiel von Algen und Tieren beim Stoffumsatz. Biol Unserer Zeit 5:301-307

Remmert H (ed) (1991) The mosaic-cycle concept of ecosystems. Ecol Stud 85. Springer, Berlin

Rösner HU (1992) Hinweise zur Durchführung der Rastvogelzählungen im schleswig-holsteinischen Wattenmeer. World Wide Fund for Nature, D-25813 Husum, p 1-13 
Smith PC (1975) A study of the winter feeding ecology of the Bar-tailed Godwit Limosa lapponica. PhD thesis, University of Durham

Spaans AL (1971) On the feeding ecology of the Herring Gull Larus argentatus Pont. in the northern part of the Netherlands. Ardea 59:3-185

Swennen CG. Nehls G, Laursen K (1989) Numbers and distribution of Eiders Somateria mollisima in the Wadden Sea. Neth $J$ Sea Res 24:83-92

Vauk G. Prüter J (1987) Möwen. Niederelbe-Verlag, Otterndorf

Wietfeld J (1977) Untersuchungen an Speiballen der Silbermöwe (Larus argentatus) im Naturschutzgebiet Großer Knechtsand (Elbe-Weser-Mündung). Die Vogelwelt 15: $221-229$

This article was submitted to the editor
Worral CM, Widdows $J$ (1984) Investigation of factors influencing mortality in Mytilus edulis L. Mar Biol Lett 5: $85-97$

Zens M. Michaelis H. Herlyn M, Reetz M (1996) Die Miesmuschelbestände der niedersachsischen Watten im. Frühjahr 1994. Berichte der Forschungsstelle Küste, Nr. 18, Norderney

Zwarts L, Blomert AM (1992) Why knot Calidris canutus take medium sized Macoma balthica when six prey species are available. Mar Ecol Prog Ser 83:113-128

Zwarts L, Drent RH (1981) Prey depletion and the regulation of predator density: oystercatchers, Haematopus ostralegus, feeding on mussels Mytilus edulis. In: Jones P, Wolff WJ (eds) Feeding and survival strategies of estuarine organisms. Plenum Press, New York, p 193-216

Manuscript first received: August 12, 1996

Revised version accepted: September 25, 1996 